\title{
Occurence of Phidotricha erigens Raganot, 1889 (Lepidoptera: Pyralidae) in corn in Brazil
}

\author{
Bolzan, A. ${ }^{a}$, Sturza, $V S^{b *}$. and Dequech, STB. ${ }^{a}$ \\ ${ }^{a}$ Departamento de Defesa Fitossanitária, Centro de Ciências Rurais, Universidade Federal de Santa Maria - UFSM, \\ Av. Roraima, Bairro Camobi, 1000, CEP 97105-900, Santa Maria, RS, Brazil

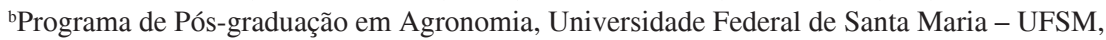 \\ Av. Roraima, Bairro Camobi, 1000, CEP 97105-900, Santa Maria, RS, Brazil \\ *e-mail: vsturza27@yahoo.com.br \\ Received November 25, 2011 - Accepted February 16, 2012 - Distributed November 30, 2012
}

(With 1 figure)

Among the factors that affect corn yields in Brazil is the occurrence of insect pests during the crop growth, especially during the reproductive phase, such as those that occur on ears. In other Latin America countries, among secondary insects is Phidotricha erigens Raganot, 1889 (Lepidoptera: Pyralidae), described to be attacking ears of corn in Peru and Colombia (Wille, 1943 apud Costa Lima, 1950, p. 83; Cajiao et al., 1984). In Brazil, it was misidentified as Pococera atramentalis Lederer, 1863 (Lepidoptera: Pyralidae) by Costa Lima (1950) (Vitor Osmar Becker, personal information) and it is reported in other cultivated species (Costa Lima, 1950; Nava et al., 2006), but there is no mention of any occurrence in corn. This work reports the first occurrence of $P$. erigens feeding on corn in Santa Maria, Rio Grande do Sul, Brazil.

An experiment of $680 \mathrm{~m}^{2}(34 \mathrm{~m} \times 20 \mathrm{~m})$ at an experimental area of "Universidade Federal de Santa Maria” (UFSM), in Santa Maria (29 43' S and 53 43' W, $95 \mathrm{~m}$ asl) was carried out from January to May, 2011. The central crop area was divided into 20 plots of 24 square meters each $(6 \mathrm{~m} \times 4 \mathrm{~m})$, and the remaining area was used as side boundaries. Sampling was performed by taking two ears randomly per plot (40 ears/sample), on a daily basis, during almost all the reproductive subperiod, from the seventh day after silking (DAS) until the $26^{\text {th }}$ DAS, with a total of 20 samples and 800 evaluated ears. Collected material was identified and sent to a laboratory, where an occurrence of larvae was observed on each ear. Afterwards, insects were counted, separated and kept individually in $100 \mathrm{~mL}$ plastic cups having an artificial diet until adult emergence for proper identification. A total of 30 P. erigens larvae were found, distributed in three different body size ranges: $<0.5 \mathrm{~cm}$ (22 larvae), $0.6-1 \mathrm{~cm}$ (3 larvae) and $>1 \mathrm{~cm}$ (5 larvae) and represented the second lowest rate among lepidopteran insects. Earworm, Helicoverpa zea Boddie, 1850; Fall armyworm Spodoptera frugiperda (J. E. Smith, 1797) (Lepidoptera: Noctuidae), and Dichomeris famulata Meyrick, 1914 (Lepidoptera: Gelechiidae) were also found, with a total of 308, 90 and 26 insects, respectively. $P$. erigens larvae occurred from the $13^{\text {th }}$ to $26^{\text {th }}$ DAS, which corresponded to 27.03.2011 to 09.04.2011dates (last sample), during the R3 and R4 corn reproductive stages. The highest infestation was on the $18^{\text {th }}$ and $23^{\text {rd }}$ DAS, with six larvae (Figure 1), totaling $15 \%$ and $12.5 \%$

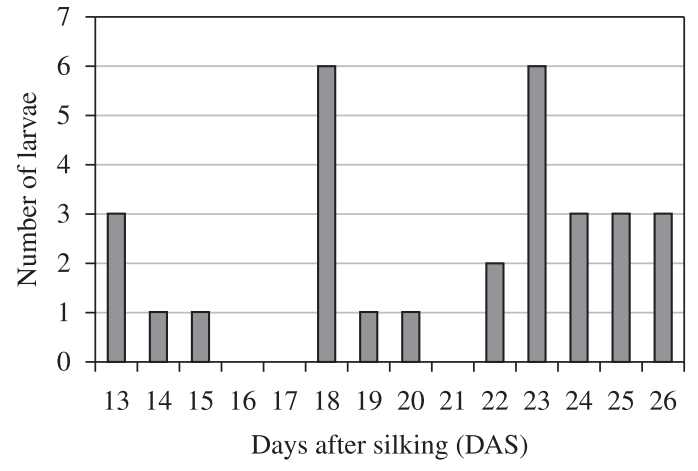

Figure 1. Number of Phidotricha erigens Raganot, 1889 larvae collected during the corn reproductive phase. Santa Maria, Rio Grande do Sul State, March/April 2011.

of evaluated corn ears infested, respectively. Likewise on the $23^{\text {rd }}$ DAS, it was the only sample in which more than one larva per ear was found (two larvae).

The record of $P$. erigens feeding on corn in Brazil demonstrates the adaptability of this insect to Brazilian subtropical conditions. This characteristic added to the diversity of host crops leads to a concern for monitoring this species even as a secondary insect pest.

Acknowledgements - The authors would like to thank Dr. Vitor Osmar Becker for identifying P. erigens and Paulo Roberto da Silva, from Pionner Sementes, for providing the corn seeds.

\section{References}

CAJIAO, VCH., RODRÍGUEZ E, OV. and PULIDO FONSECA, JI., 1984. Ciclo de vida y hábitos de Pococera atramentalis Lederer (Pyralidae) plaga de la panoja de sorgo. Acta Agronómica, vol. 34, p. 53-58.

COSTA LIMA, AM., 1950. Insetos do Brasil: Lepidópteros. Rio de Janeiro: Escola Nacional de Agronomia, 420 p. $6^{\circ}$ tomo, $2^{\mathrm{a}}$ parte.

NAVA, DE., FORTES, P., DE OLIVEIRA, DG., VIEIRA, FT., IBELLI, TM. and GUEDES, JC., 2006. Platynota rostrana (Walker) (Tortricidae) and Phidotricha erigens Raganot (Pyralidae): artificial diet effects on biological cycle. Brazilian Journal of Biology, vol. 66, p. 1037-1043. http://dx.doi.org/10.1590/S151969842006000600010 
